\title{
An Investigation of Punching the MWCNTs Doped Composite Plates by Using Different Cutting Profiles
}

\author{
Ferhat CERITBINMEZ, Ahmet YAPICl*
}

\begin{abstract}
In this study, glass fiber reinforced composite layers which are with and without additives of 0.1 wt. \% multi walled carbon nanotubes (MWCNTs) of epoxy were manufactured by vacuum infusion method. Unlike the conventional methods, punching was used in processing and drilling of these materials. The 62 - $64 \mathrm{HRC}$ hard punches made of 1.3343 material with specially designed $90^{\circ}, 30^{\circ}, 15^{\circ}, \mathrm{V}, \mathrm{C}$ profiles were used for punching of composites. Additionally, made of 1.2379 material with $62-64 \mathrm{HRC}$ hardness, the mold with $0.05,0.01$ and $0.16 \mathrm{~mm}$ clearance values was used. Fujfilm prescale and chatillon load cell were used for force measurement that showed the pressure applied by punches with different cutting profiles. Hole diameter, delamination and burring were analyzed by $3 \mathrm{~d}$ laser scanner. In test values with mold's $0.05 \mathrm{~mm}$ clearance, no burr was observed. The cutting surface of MWCNTs doped composite materials was found to be cleaner and material strength was higher.
\end{abstract}

Keywords: GFRP; laser scanner; load cell; machinability; nanocomposite; punching

\section{INTRODUCTION}

Composite materials, which have an important place in many fields from past to present, are mostly used in the aircraft applications, sporting goods, space equipments, marine, automotive, electrical and industrial systems, orthopedic parts and constructions industry [1-6]. The main reasons for the choice of composite materials are high endurance and stiffness, low weight, low specific gravity and strength ratio, high corrosion resistance, durable, good insulation and relatively low costs [7-8]. Composite materials can be reinforced with carbon nanotubes [9]. MWCNTs have points of interest over different materials because of their better quality than weight proportions, colossal firmness, high conductivity, high adaptability and low thickness [10]. Different enterprises, for example, car, aviation, maritime and petroleum ventures, have just begun the use of MWCNTs doped materials in their structures. In general, all the composite materials go through some manufacturing processes during production or at the place of installation [11]. The holes required for bolts, rivets and pin connections are formed by the drilling method, though drilling with a drill is a complicated process due to chip removal with a rotating cutting tool. [12-13]. Glass fiber reinforced plastics (GFRP) are neither isotropic nor homogeneous, drilling reveals specific problems in the area around the hole that may be associated with aftereffect damage [14]. Delamination, fiber pull-out, interlaminar cracking, or thermal damage (matrix burning) are the most common defects caused by drilling [15-17]. Drilling in the aerospace industry, accounts for approximately $40 \%$ of all the material removal operations [18]. Those parts become unusable due to damage caused during the processing and drilling of composite structures. $60 \%$ of the parts are not accepted due to their size, size tolerance, precision, especially in the aviation industry [19]. In order to assemble the produced composites to the place of use, dimensional accuracy and surface precision are important; accurate machining method and parameters are needed. Kishore and Kuppan [20] have investigated a precise drilling of current state of fiber-reinforced polymer and composite laminates of nanopolymer. Cunningham et al. [17] investigated the infulunce of cryogenic $\mathrm{CNC}$ processing on the edge cutting performance of carbon fiber reinforced plastics (CFRP) for the multi-tooth and updown UD cutting tool. DeFu Liu et al. [21] reviewed on mechanical drilling of composite materials; including drilling operations, geometry and materials of drill bit, drilling-induced delamination, thrust force, wear of tools, delamination reduction approaches and certain marked characteristics during the fiber metal laminates (FML) drilling. Yasuhiro Kakinuma et al. [22] recommended ultrafast feed drilling (UFFD) to obtain holes in Carbon fiber reinforced thermoplastics sheet with thermoplastic binding. The validity of the study was confirmed by experimental comparison of ultrasonic vibration-assisted drilling (UVD) and abrasive water jet machining (AWJ). Ameur et al. [23] analyzed application of response surface methodology (RSM) models to the analysis of the effect of machining parameters on thrust strength, torque, factor of exit delamination and error of cylindricity. Abdullah and Bailey [24] developed a three-dimensional finite element model to provide further insight into the punching behaviour of such column-slab connections. The findings were described in terms of relationships of load deflection, failure modes, ultimate load capacity, stresses in the steel reinforcement and CFRP plates, interfacial slip and stress distribution. Qiao et al. [25] investigated processing Zr36.6Ti31. 4Nb7Cu5.9Be19.1 metallic glass matrix composites (MGMC). To process MGMC, a dynamic shear punching system was used through a crank press and die cutting machine. Punch forming was used and mechanical behavior was investigated by them. Chan et al. [26] recommended the punching method and evaluated the effect of the die clearance on the quality of the produced holes. Zain et al. [27] focused on the effect of different puncher types on the quality of punched holes. They reported that delamination is critical to ensuring that the assembled composite panels are strongly attached to the produced hole. Abdullah et al. [28] have investigated information about delamination assessment of punched holes on laminated composite panels based on the profile measurement technique. Main goal of their research was to quantify damage of delamination around the holes created using the punching device. 
Although there are many studies on drilling of composite materials, less research has been made on punching. In this study, composite materials with better mechanical properties have been manufactured with the contribution of the MWCNTs. It was emphasized that the need for the installation of materials in many areas could be met without the creation of sawdust powders which would damage the environment and human health by using the punching method. As a result of the drilling process, delaminations in composite structures, splintering, burring, were not observed. Successful results were obtained with punches with different cutting profiles and clearance values of the mold.

\section{MATERIALS AND METHODS}

\subsection{Manufacturing of Composite Plates}

Pure and MWCNTs doped GFRP composite laminates were produced using 8 plies with $300 \times 300 \mathrm{~mm}$ in dimension $\left(0 / 90^{\circ}\right.$ fiber orientation angle, $200 \mathrm{~g} / \mathrm{m}^{2}$ areal weight), $300 \mathrm{~g}$ epoxy resin and $75 \mathrm{~g}$ hardener by vacuum infusion method (VIM). The mixture of epoxy resin and hardener, (hexion MGS LR160 and MGS LH160 respectively) was at the ratio of $4: 1$. The mechanical specifications of the reinforcement and matrix are given in Tab. 1. Finally, the hardener was added to the beaker and mixed with the resin-MWCNTs mixture and then nano composite plates were produced with VIM (Fig. 1). Thickness of the composites produced was $1.6 \pm 0.1 \mathrm{~mm}$.

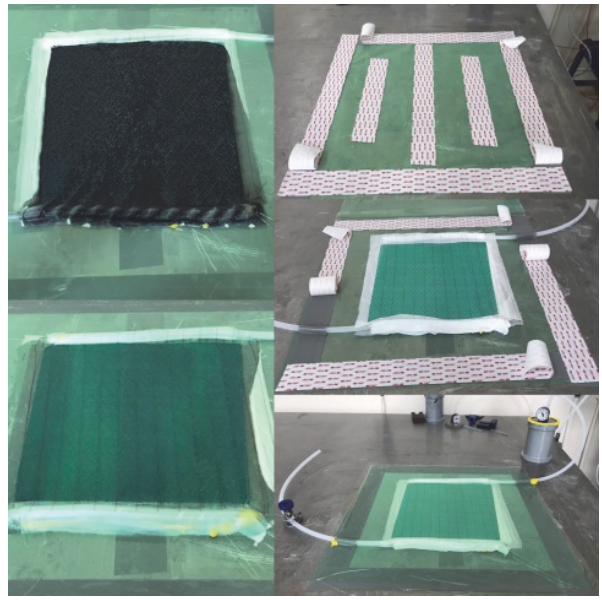

Figure 1 Composite laminates manufacturing

\begin{tabular}{|c|c|c|c|c|c|}
\hline \multicolumn{2}{|c|}{$\begin{array}{l}\text { Glass-Fiber cross-ply } \\
\text { / 0/90 symmetric }\end{array}$} & \multicolumn{2}{|c|}{$\begin{array}{c}\text { Mechanical data of neat resin } \\
\text { Curing: } 24 \text { h at } 23^{\circ} \mathrm{C}+15 \text { h at } 60{ }^{\circ} \mathrm{C}\end{array}$} & \multicolumn{2}{|c|}{$\begin{array}{l}\text { Carbon Nanotubes } \\
\text { (Black), purity }>90 \%\end{array}$} \\
\hline Diameter of fiber / $\mu \mathrm{m}$ & 7 & Density $/ \mathrm{g} / \mathrm{cm}^{3}$ & $1.18-1.2$ & Tap density $/ \mathrm{g} / \mathrm{cm}^{3}$ & 0.14 \\
\hline Density $/ \mathrm{g} / \mathrm{cm}^{3}$ & 2.6 & Flexural strength / MPa & $110-140$ & True density $/ \mathrm{g} / \mathrm{cm}^{3}$ & 2.1 \\
\hline Tensile strength / MPa & 3.5 & Tensile strength / MPa & $70-80$ & Outside diameter / nm & $10-30$ \\
\hline Tensile modulus / GPa & 72 & Modulus of elasticity / GPa & $3.2-3.5$ & Inside diameter / nm & $5-10$ \\
\hline Elongation at break / \% & 4.8 & Elongation at break / \% & $5.0-6.5$ & Length $/ \mu \mathrm{m}$ & 30 \\
\hline
\end{tabular}

\subsection{Manufacture of Punches with Different Cutting Profiles}

The $ø 8 \mathrm{~mm}$ punches that have $90^{\circ}, 15^{\circ}, 30^{\circ}, \mathrm{V}, \mathrm{C}$ different cutting profiles, have been manufactured by charmilles robofil 290P wire electro discharge machining
(WEDM) (Fig. 2). $90^{\circ}$ type where strength is required, $15^{\circ}$ and $30^{\circ}$ type where less strength is required, type $\mathrm{V}$ where shear is performed and type $\mathrm{C}$ for perforator are widely used in industry.
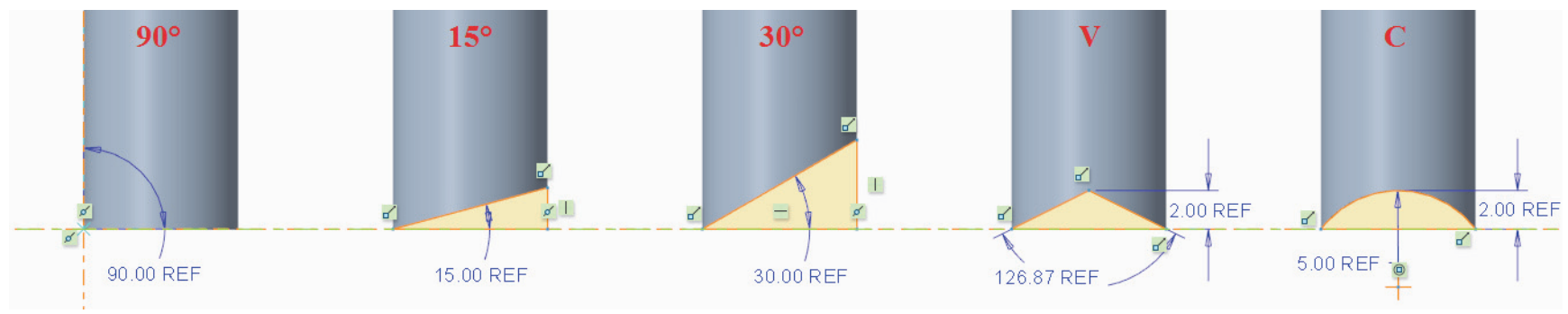

Figure 2 Punch end configurations

The $\mathrm{V}$ type crisscross shear reduces material deformation on thin material. $90^{\circ}$ type has flate face for punching thin or thick material, or when the slug is being saved. The $\mathrm{C}$ type concave shear, reduces material deformation on thin material. $15^{\circ}$ and $30^{\circ}$ types have unbalanced shear.

\subsection{Manufacture of Pad and Die Molds}

A punching mold was designed and manufactured to make hole in the composite plates. OD:30 mm-ID:8 mm washers, $\varnothing 20 \mathrm{~mm} \times 10 \mathrm{~mm}$ blue springs and 1.2379 materials (pad and die steel) $(62-64 \mathrm{HRC} \pm 2)$ have been used during the punching. Die had three different holes which were $0.05 \mathrm{~mm}, 0.10 \mathrm{~mm}, 0.16 \mathrm{~mm}$ clearance values (Fig. 3). Puncher life, hole edge quality and cost per hit depend on the optimal die clearance.

All of the laminates were punched by workshop type manual hydraulic press. The punch cutting speed of the press was $5 \mathrm{~mm} / \mathrm{min}$. Punching mold was put on the work table plate of the hydraulic press and then force was applied to the punch head by piston ram. All the parts were vertically aligned. 


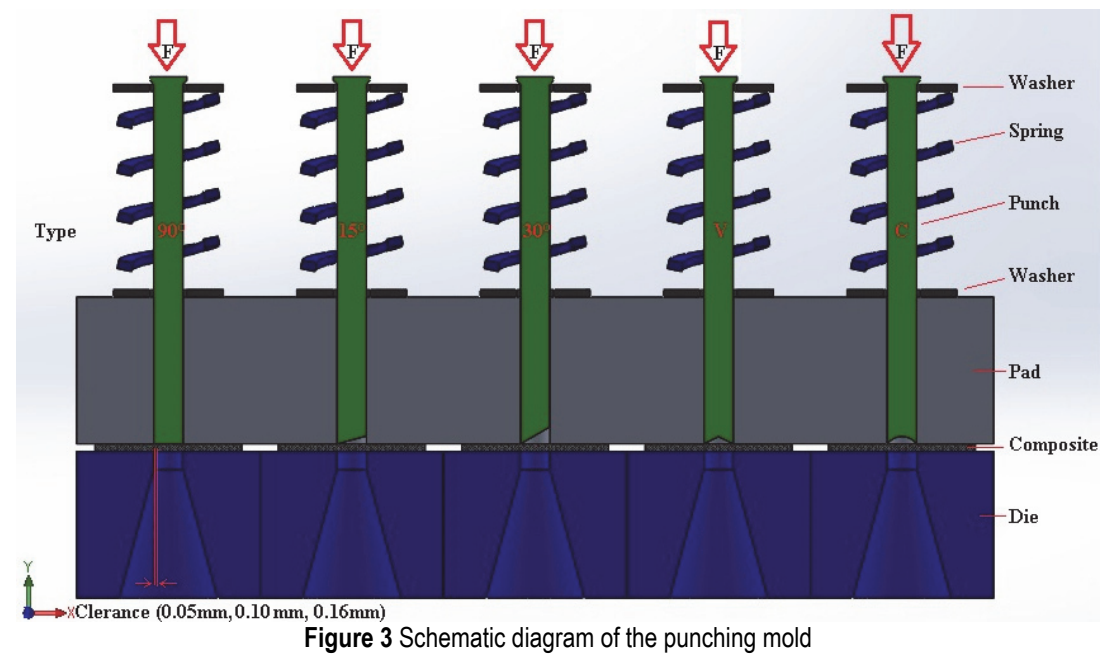

\subsection{Force Measurement by Ametek Chatillon (Load Cell) and Fujifilm Prescale}

Fujifilm Prescale is an industrial film in which one can see the pressure distribution and parallelism on the surface. Pressure measurement film shows differences in pressure applied as variations in red color size. When the pressure is applied to the film, the microcapsules inside explode to form a red color on the film. The pressure distribution is seen according to the intensity of the red color, which is formed on the film (Fig. 4).

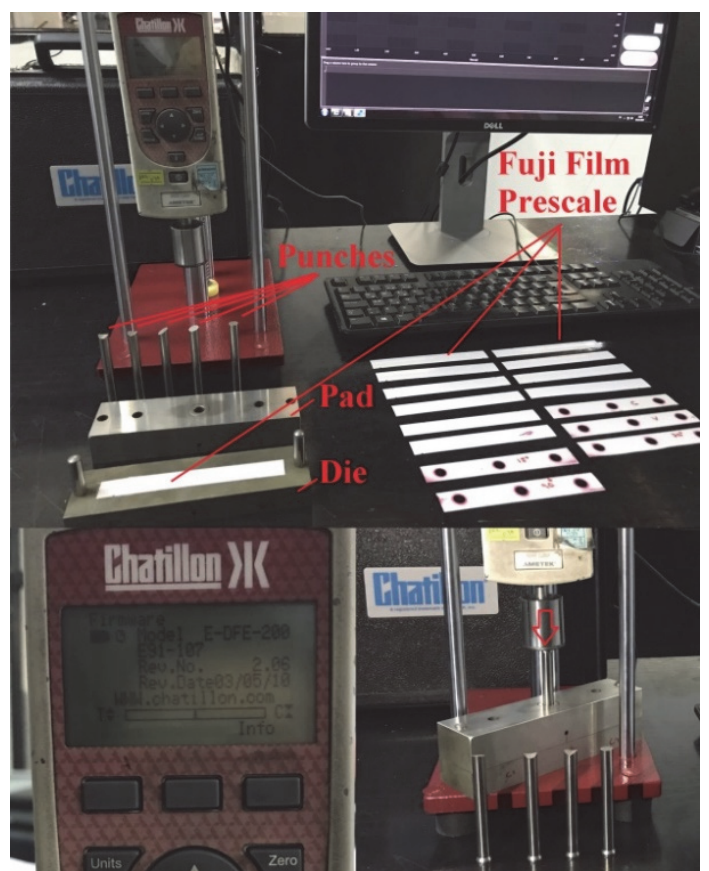

Figure 4 Working members of the force measurement apparatus

There are a lot of areas where the load cells are used, one of them is Hwang's implementation; to investigate the effect of the $\mathrm{ZnO}$ nanowire interface on the ballistic response of aramid fabrics, the sliding friction between tows was calculated by the guided transverse tension tow pull-out test [29]. In this study; $20{ }^{\circ} \mathrm{C}-30{ }^{\circ} \mathrm{C}$ ambient temperature and 35\% RH - 80\% RH (Relative Humiditiy), medium $110 \mu \mathrm{m}$ thick mono sheet type pressure gauge was put between the pad and die mold; pressure changes were gauged applying Ametek Chatillon (Load Cell) during and after the cutting.

\subsection{Dimensional Control by Romer Absolute Arm Line Laser Scanner}

Romer absolute arm is an industrial device with many uses such as quality control, inspection, on-machine verification, reverse engineering, virtual assembly or the 3D modelling. Automotive, aerospace, railway, forming industry are some of the typical industries where romer is used; besides the typical measuring applications are composites inspection, sheet metal parts, jigs and fixture setup and alignment, reverse engineering etc. Test specimens were fixed separately by mitutoyo clamping and then they were measured by RA - 7320 SI hexagon romer absolute arm (Fig. 5). $\varnothing 3 \mathrm{~mm}$ probe was used for measuring the hole diameter, additionally $\varnothing 6 \mathrm{~mm}$ probe was used for measuring surface scanning (0.01 mm accuracy). All the specimens were scanned by PolyWorks Inspector Premium. The mesh structure of the specimens with hole diameters and 3D measurements were examined and then the output was taken as an STL file and examined in Solidworks CAD program.

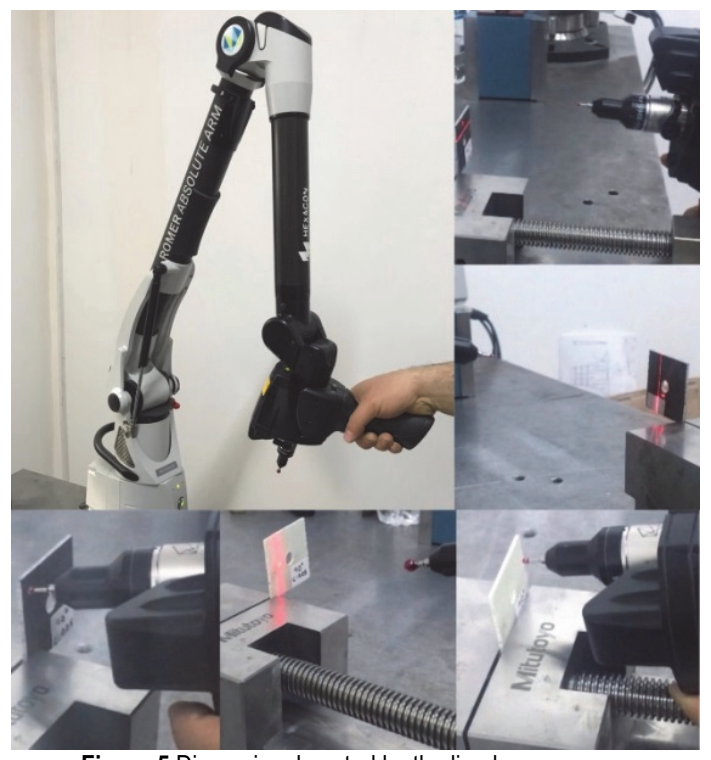

Figure 5 Dimensional control by the line laser scanner 


\section{$3 \quad$ RESULTS AND DISCUSSIONS}

Table 2 Mechanical properties of pure composite and MWCNTs doped

\begin{tabular}{|c|c|c|c|c|c|c|}
\hline \multicolumn{7}{|c|}{ composite } \\
\hline Materials & 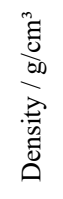 & 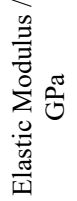 & 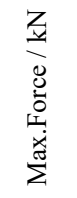 & 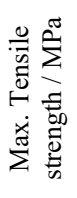 & 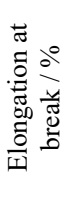 & 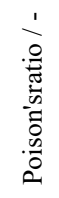 \\
\hline Pure Composite & 1.62 & 23 & 13.74 & 339 & 2.16 & 0.14 \\
\hline Doped Composite & 1.59 & 25 & 14.53 & 364 & 1.29 & 0.15 \\
\hline
\end{tabular}

Mechanical properties of pure composite and MWCNTs doped composite are given in Tab. 2. According to tensile test results of composite materials produced, mechanical properties of doped composite were better than those of the pure composites. The high elastic modulus and tensile strength of MWCNTs have contributed to the composite structure.

\subsection{Force Measurement and Pressure Distribution Evaluation}

In this study, pressures applied by different punches to cut 110 microns thick fuji film are shown. Too small clearance causes less than optimal fracture and excessive forces; and too large clearance causes oversized burr [30]. Too little of the clearance causes the punch to jam when cutting the material and increase the pressure.

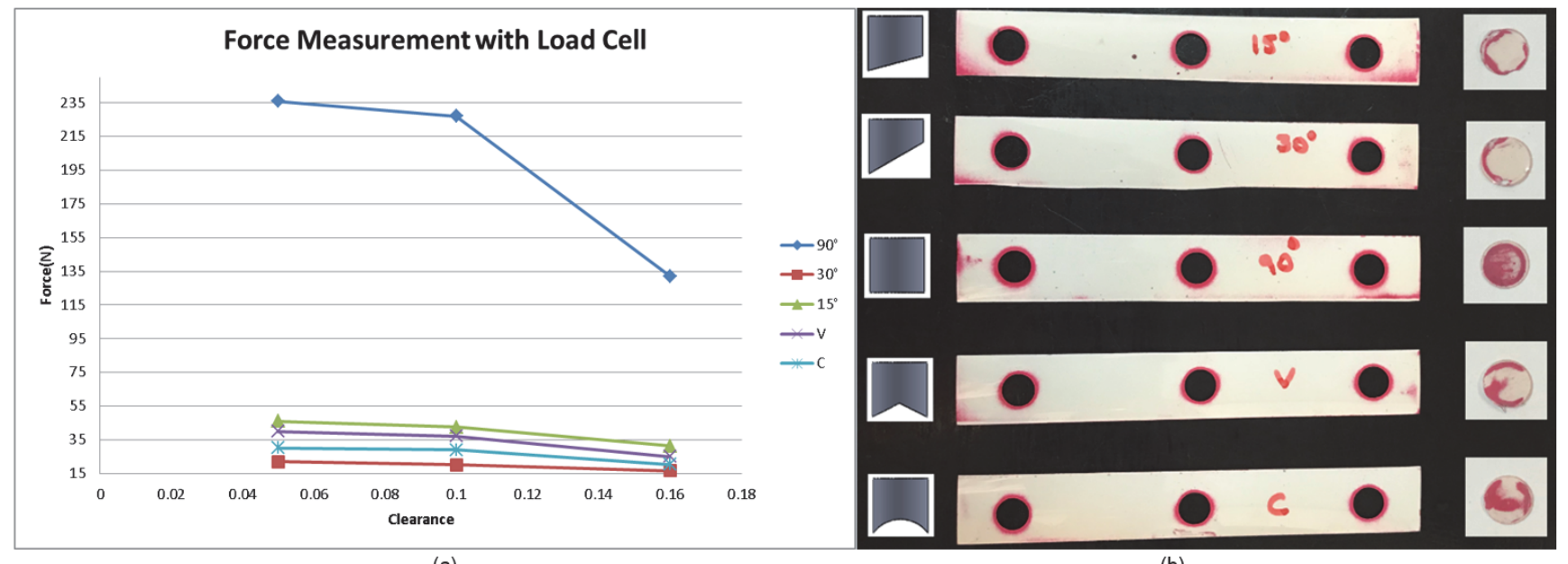

(a)

(b)

Figure 6 Effect of clearance and punch profile on force change (a) force measurement (b) pressure effect

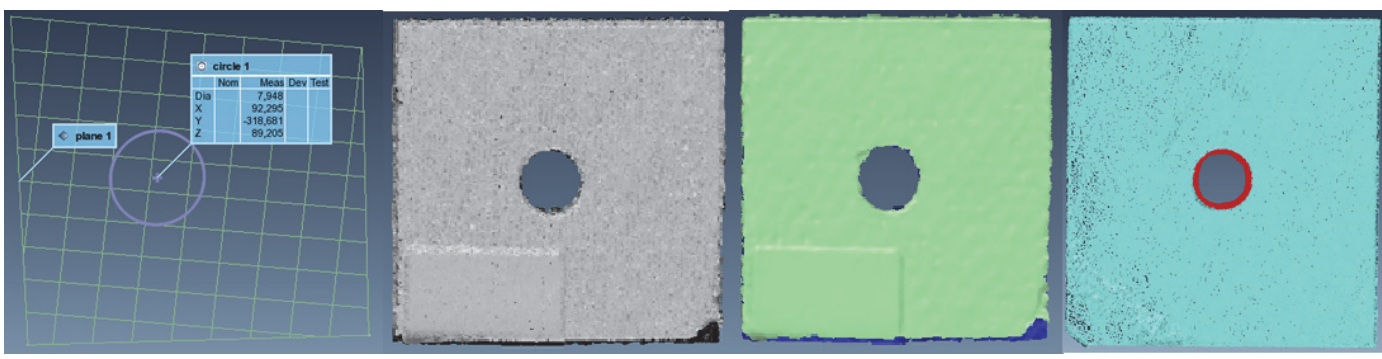

Figure $73 \mathrm{D}$ test samples and hole diameter detection by laser scanner

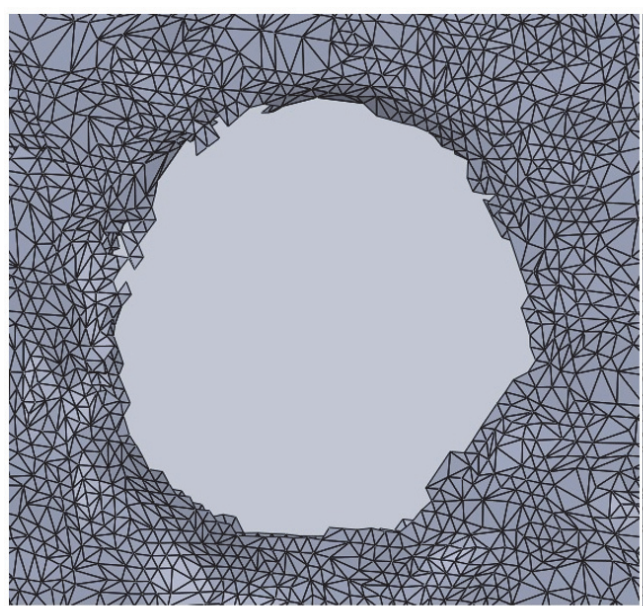

(a)

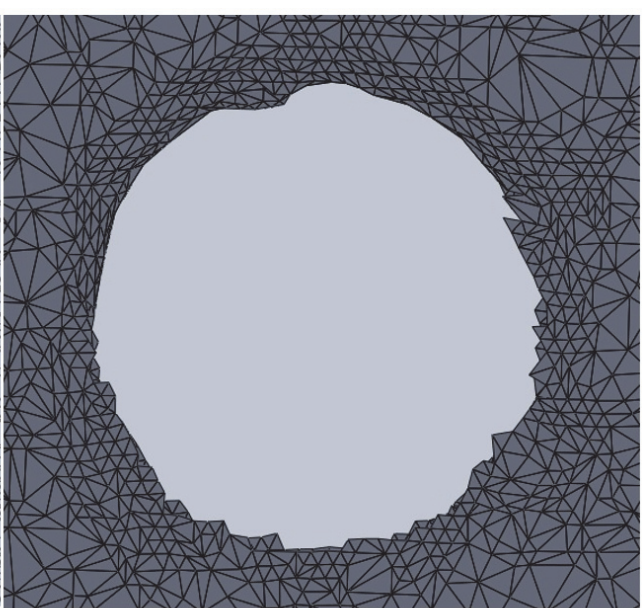

Figure 8 Mesh structure of the holes (a) pure composite (b) doped composite 
Shear stress and compressive stress were effective on the pressure changes as a consequence of clearance values. In addition, in this study the pressure applied to the cutting process with the lowest clearance was the greatest. As the punch surface increased, the pressure increased and the capsules in the pressure gauge exploded to show a dark color. With the angled punches, the points where V, C type punches cut the mono sheet increased the staining due to pressure. When the cut parts were examined, the highest pressure was determined on the $90^{\circ}$ punch. The increase of the clearance reduced the cutting pressure and decreased the color. As the angle of the cutting punch increased, the cutting pressure decreased (Fig. 6).

\subsection{Dimensional Control by Romer Absolute Arm Line Laser Scanner}

The hole dimensions and cutting edges of the punched composite sheets were examined using the Romer laser measuring device. Fig. 7 shows formation of a solid model and the determination of the hole diameter by the laser scanning after the drilling of composite materials.

When the mesh structure of the specimens was examined after laser scanning, it was seen that the nanocomposite structures had a more rigid and regular cutting surface. (Fig. 8).

\subsection{Key Findings}

Hole diameters of the pure composite were bigger than those of the doped composite, because the doped composite was stronger than pure one; when the punches cut them, nanocomposite did not yawn. Fig. 9 shows the increase of the clearance value caused by increase of hole diameter. The largest hole diameter was obtained using a $\mathrm{C}$ type punch, the smallest hole diameter was obtained using $15^{\circ}$ type punch. Most of results were burr-free but some of them were burry because of higher clearance.

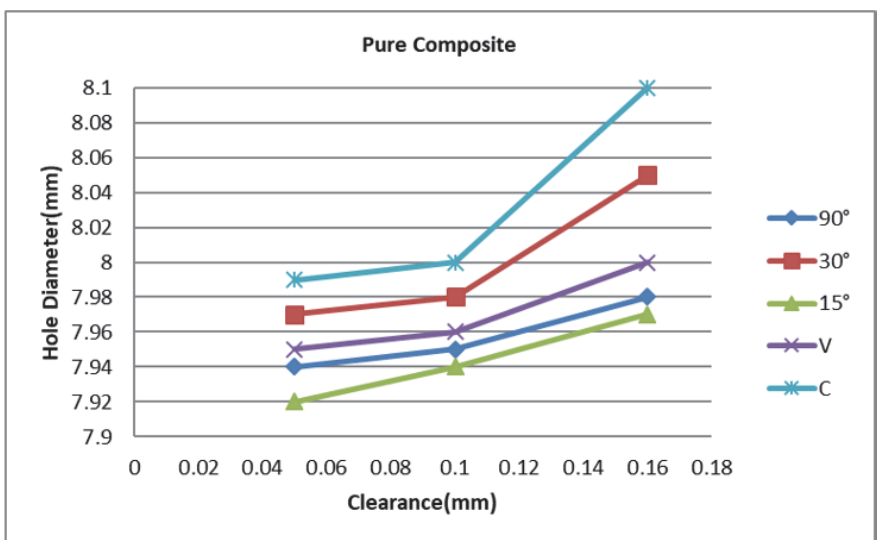

(a)

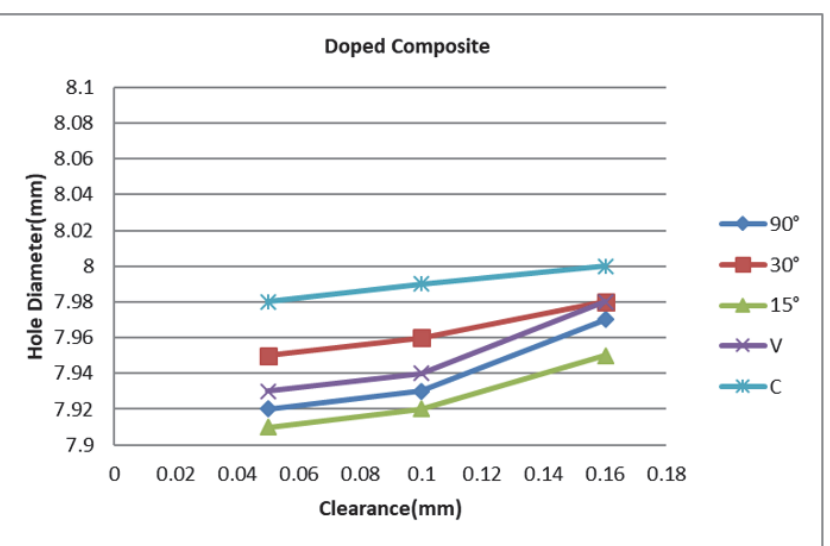

(b)

Figure 9 Hole diameter changes of pure- doped composite depend on clearance

\section{CONCLUSIONS}

There are a lot of areas that use punching method for machinability in industry. In this study, punching technique has been implemented successfully for piercing of composite materials by using different punches.

It was determined that the composite materials, produced with $0.1 \%$ MWCNTs additive, were stronger than the pure samples. Low density, high elastic modulus and tensile strength were obtained with nanoparticles.

In the measurements made by using Load Cell and fujifilm prescale, it was determined that the cutting force increased with increase of the punch press surface. The maximum shear force was measured in $90^{\circ}$ type punch, and the minimum shear force was measured in the $\mathrm{C}$ type punch. When the fujifilm prescale color results were examined, the largest color change was observed in the $90^{\circ}$ form punch and the least color change was observed in the C type punch.

The cutting force reduced and hole diameter increased because of increasing the clearance value.

The holes obtained using the $\varnothing 8 \mathrm{~mm}$ punch were found to be smaller than the punch diameter. The hole diameters of the nanoparticle composite structures were determined to be smaller than the ones of the pure composite. The nanoparticle admixture added stability to the composite structure and the cutting surfaces were more uniform.

\section{REFERENCES}

[1] Mazumdar, S. K. (2007). Composites ManufacturingMaterials. Product and Process Engineering, 13-19.

[2] Mallick, P. K. (2007). Fiber-reinforced composites: materials, manufacturing, and design. CRC press. https://doi.org/10.1201/9781420005981

[3] Singh, A. P., Sharma, M., \& Singh, I. (2013). A review of modeling and control during drilling of fiber reinforced plastic composites. Composites Part B: Engineering, 47, 118-125. https://doi.org/10.1016/j.compositesb.2012.10.038

[4] Sankar, B. R., Umamaheswarrao, P., Reddy, A. A., \& Kumar, P. K. (2014). Drilling of composite laminates: a review. J Basic Appl Eng Res, 1(3), 19-24.

[5] Bonnet, C., Poulachon, G., Rech, J., Girard, Y., \& Costes, J. P. (2015). CFRP drilling: Fundamental study of local feed force and consequences on hole exit damage. International Journal of Machine Tools and Manufacture, 94, 57-64. https://doi.org/10.1016/j.jimachtools.2015.04.006

[6] Ismail, S. O., Dhakal, H. N., Popov, I., \& Beaugrand, J. (2016). Comprehensive study on machinability of sustainable and conventional fibre reinforced polymer composites. Engineering Science and Technology, an International Journal, 19(4), 2043-2052. https://doi.org/10.1016/j.jestch.2016.07.010 
[7] Takahashi, K., Tsukamoto, M., Masuno, S., \& Sato, Y. (2016). Heat conduction analysis of laser CFRP processing with IR and UV laser light. Composites Part A: Applied Science and Manufacturing, 84, 114-122. https://doi.org/10.1016/j.compositesa.2015.12.009

[8] Riveiro, A., Quintero, F., Lusquiños, F., Del Val, J., Comesaña, R., Boutinguiza, M., \& Pou, J. (2012). Experimental study on the $\mathrm{CO} 2$ laser cutting of carbon fiber reinforced plastic composite. Composites Part A: Applied Science and Manufacturing, 43(8), 1400-1409. https://doi.org/10.1016/j.compositesa.2012.02.012

[9] Oliveira, V., Sharma, S. P., De Moura, M. F. S. F., Moreira, R. D. F., \& Vilar, R. (2017). Surface treatment of CFRP composites using femtosecond laser radiation. Optics and Lasers in Engineering, 94, 37-43. https://doi.org/10.1016/j.optlaseng.2017.02.011

[10] Chaudhury, P. \& Samantaray, S. (2017). Role of Carbon Nano Tubes in Surface Modification on Electrical Discharge Machining-A Review. Materials Today: Proceedings, 4(2), 4079-4088. https://doi.org/10.1016/j.matpr.2017.02.311

[11] Panchagnula, K. K. \& Palaniyandi, K. (2018). Drilling on fiber reinforced polymer/nanopolymer composite laminates: a review. Journal of materials research and technology, 7(2), 180-189. https://doi.org/10.1016/j.jmrt.2017.06.003

[12] Marques, A. T., Durão, L. M., Magalhães, A. G., Silva, J. F., \& Tavares, J. M. R. (2009). Delamination analysis of carbon fibre reinforced laminates: evaluation of a special step drill. Composites Science and Technology, 69(14), 2376-2382. https://doi.org/10.1016/j.compscitech.2009.01.025

[13] Durão, L. M. P., Gonçalves, D. J., Tavares, J. M. R., de Albuquerque, V. H. C., Vieira, A. A., \& Marques, A. T. (2010). Drilling tool geometry evaluation for reinforced composite laminates. Composite structures, 92(7), 15451550. https://doi.org/10.1016/j.compstruct.2009.10.035

[14] Arul, S. V. L. M. S., Vijayaraghavan, L., Malhotra, S. K., \& Krishnamurthy, R. (2006). The effect of vibratory drilling on hole quality in polymeric composites. International Journal of Machine Tools and Manufacture, 46(3-4), 252-259. https://doi.org/10.1016/j.jimachtools.2005.05.023

[15] Davim, J. P. \& Reis, P. (2003). Drilling carbon fiber reinforced plastics manufactured by autoclave-experimental and statistical study. Materials \& design, 24(5), 315-324. https://doi.org/10.1016/S0261-3069(03)00062-1

[16] Abrao, A. M., Faria, P. E., Rubio, J. C., Reis, P., \& Davim, J. P. (2007). Drilling of fiber reinforced plastics: A review. Journal of Materials Processing Technology, 186(1-3), 1-7. https://doi.org/10.1016/j.jmatprotec.2006.11.146

[17] Cunningham, C. R., Shokrani, A., \& Dhokia, V. (2018). Edge trimming of carbon fibre reinforced plastic. Procedia CIRP, 77, 199-202. https://doi.org/10.1016/j.procir.2018.08.285

[18] Tsao, C. C. \& Hocheng, H. (2007). Effect of tool wear on delamination in drilling composite materials. International journal of mechanical sciences, 49(8), 983-988. https://doi.org/10.1016/j.jmecsci.2007.01.001

[19] Khashaba, U. A. (2004). Delamination in drilling GFRthermoset composites. Composite Structures, 63(3-4), 313327. https://doi.org/10.1016/S0263-8223(03)00180-6

[20] Panchagnula, K. K. \& Palaniyandi, K. (2018). Drilling on fiber reinforced polymer/nanopolymer composite laminates: a review. Journal of materials research and technology, 7(2), 180-189. https://doi.org/10.1016/j.jmrt.2017.06.003

[21] Liu, D., Tang, Y., \& Cong, W. L. (2012). A review of mechanical drilling for composite laminates. Composite structures, 94(4), 1265-1279. https://doi.org/10.1016/j.compstruct.2011.11.024

[22] Kakinuma, Y., Ishida, T., Koike, R., Klemme, H., Denkena, B., \& Aoyama, T. (2015). Ultrafast feed drilling of carbon fiber-reinforced thermoplastics. Procedia CIRP, 35, 91-95. https://doi.org/10.1016/j.procir.2015.08.074
[23] Ameur, M. F., Habak, M., Kenane, M., Aouici, H., \& Cheikh, M. (2017). Machinability analysis of dry drilling of carbon/epoxy composites: cases of exit delamination and cylindricity error. The International Journal of Advanced Manufacturing Technology, 88(9-12), 2557-2571. https://doi.org/10.1007/s00170-016-8967-8

[24] Abdullah, A. \& Bailey, C. G. (2018). Punching behaviour of column-slab connection strengthened with non-prestressed or prestressed FRP plates. Engineering Structures, 160, 229242. https://doi.org/10.1016/j.engstruct.2018.01.030

[25] Qiao, J. W., Ye, H. Y., Yang, H. J., Liang, W., Xu, B. S., Liaw, P. K., \& Chen, M. W. (2013). Dynamic shear punching of metallic glass matrix composites. Intermetallics, 36, 3135. https://doi.org/10.1016/j.intermet.2012.12.016

[26] Chan, H. Y., Abdullah, A. B., \& Samad, Z. (2015). Precision punching of hole on composite panels.

[27] Zain, M. S. M., Abdullah, A. B., \& Samad, Z. (2017). Effect of puncher profile on the precision of punched holes on composite panels. The International Journal of Advanced Manufacturing Technology, 89(9-12), 3331-3336. https://doi.org/10.1007/s00170-016-9339-0

[28] Abdullah, A. B., Zain, M. S. M., \& Samad, Z. (2017). Delamination assessment of punched holes on laminated composite panels based on the profile measurement technique. The International Journal of Advanced Manufacturing Technology, 93(1-4), 993-1000. https://doi.org/10.1007/s00170-017-0545-1

[29] Hwang, H. S., Malakooti, M. H., Patterson, B. A., \& Sodano, H. A. (2015). Increased interyarn friction through $\mathrm{ZnO}$ nanowire arrays grown on aramid fabric. Composites Science and Technology, 107, 75-81. https://doi.org/10.1016/j.compscitech.2014.12.001

[30] Groover, M. P. (2007). Fundamentals of modern manufacturing: materials processes, and systems. John Wiley \& Sons.

\section{Contact information:}

Ferhat CERITBINMEZ, PhD. Mechanical Engineer

Iskenderun Technical University, Department of Mechanical Engineering,

Iskenderun 31200, Hatay, Turkey

E-mail: ferhatceritbinmez@gmail.com

Ahmet YAPICI, Full Professor

(Corresponding author)

Iskenderun Technical University, Department of Mechanical Engineering,

Iskenderun 31200, Hatay, Turkey

E-mail: ahmet.yapici@iste.edu.tr 